\section{USE OF BIOSAN PRODUCT FOR INTENSIFICATION OF BIOLOGICAL WASTEWATER PROCESSING AT MEAT PROCESSING PLANTS}

Institute of Hydrobiology, NASU, Kyiv, Ukraine Unilos-Ukraine, Kyiv, Ukraine

The aim of our work was to study the effect of the biological product "BioSan" on the structure and functioning of activated sludge SBR-reactor during wastewater treatment of a meat processing plants. The local treatment facilities of the meat processing plant have been operating since 2014 as part of: the grease trap, averager, the filter, a pressure flotator with a preliminary input of a coagulant and flocculant, SBR-reactor, the biofilter loaded with a zeolite substrate and the contact reservoir for introducing polyhexamethylenehuinidine chloride solution. This purification scheme did not provide at the output the normative quality of return water in terms of organic pollution $\left(\mathrm{COD}, \mathrm{BOD}_{5}\right)$ and ammonium nitrogen. One of the main reasons is the presence of the slaughterhouse at the meat processing plant. In this regard, dissolved difficultly oxidized compounds, and in particular, blood, which were not removed during physicochemical treatment, were present in the wastewater. So, transparent wastewater with intense pink color and the following hydrochemical characteristics was delivered to the SBR-reactor: COD reached $1500 \mathrm{mg} \mathrm{dm}^{-3}, \mathrm{BOD}_{5}$ was $480 \mathrm{mg} \mathrm{dm}^{-3}$, and the concentration of saline ammonia nitrogen was $67 \mathrm{mg} \mathrm{dm}^{-3}$. After biological purification, the COD was $120 \mathrm{mg} \mathrm{dm}^{-3}, \mathrm{BOD}_{5}-40 \mathrm{mg} \mathrm{dm}^{-3}$, the concentration of saline ammonia nitrogen $-32 \mathrm{mg} \mathrm{dm}^{-3}$. To intensify the operation of treatment facilities, "BioSan" biological product was used, which included groups of eutrophic bacteria in the amount of about $10^{11}$ cells (Bacillus subtilis, Bacillus lichenformis, Lactobacillus acidophilus, Enterococcus faecium, Clostridium butyricum), as well as xylan (up to 700 units $\mathrm{g}^{-1}$ ), cellulase (up to 40 units $^{-1}$ ) and protease (up to 4 units $\mathrm{g}^{-1}$ ) enzymes. The biological product was dosed into the averager in the form of $10 \%$ suspension at the rate of $0.21 \mathrm{~m}^{-3}$ of wastewater. The use of the biological product began in 2019. As a result, already in the averager, the microorganisms of the biological product "BioSan" decomposed difficultly oxidized dissolved contaminants. After further physicochemical purification, the transparent wastewater with COD was $650 \mathrm{mg} \mathrm{dm}^{-3}, \mathrm{BOD}_{5}-328 \mathrm{mg} \mathrm{dm}^{-3}$, and the concentration of saline ammonia 


\section{Programm Abstracts}

nitrogen was $34 \mathrm{mg} \mathrm{dm}^{-3}$ entered the SBR-reactor. Further biological treatment of return water reduced COD was $80 \mathrm{mg} \mathrm{dm}^{-3}, \mathrm{BOD}_{5}-15 \mathrm{mg} \mathrm{dm}^{-3}$, concentration of saline ammonium nitrogen $-2 \mathrm{mg} \mathrm{dm}^{-3}$.

Microbiological monitoring was carried out quarterly during 2017-2019. We studied the species composition, concentration and sedimentation rate of activated sludge, the physiological state of organisms, sludge index. Live samples of activated sludge were not preserved upon delivery; inspection was performed under the Axio Imager A1 (Zeiss) microscope on the day of sampling. Prior to introducing the biological product into the averager in the SBR-reactor as a result of microscopy of live samples of activated sludge, organisms in the unsatisfactory physiological state, which developed in the absence of both phases of the nitrification process, were most often encountered. Activated sludge often had a low sedimentation rate, its concentration by volume was average $95 \%$ vol., and on dry matter - average 6.5 $\mathrm{g} \mathrm{dm}^{-3}$, the sludge index - average 180 . The above described characterized activated sludge as swelling. Most often, organisms such as amoeba and colorless protozoa were recorded in it (for example, Amoeba, Paramaecium, Flagellatae, Coipoda, Bodo, Vorticella). After the systematic introduction of a biological product, the situation in terms of qualitative and quantitative estimates of activated sludge has changed. So, the status of the physiological state of activated sludge organisms has changed, due to the development of organisms characteristic of both nitrification phases. These include some types of amoeba, colorless protozoa, ciliates and rotifers (for example, Acrella, Centropyxic, Carhesium, Epistylis, Anisonema, Aspidisca, Epistylis, Cathypna, Resticula, Monommata, Nematodes). Active sludge had a high and medium sedimentation rate, its concentration by volume was average $25 \%$ vol., and on dry matter - average $4 \mathrm{~g} \mathrm{dm}^{-3}$, sludge index - average 43 . Thus, the studies have confirmed the effectiveness of the use of the biological product "BioSan" in the treatment of wastewater from meat processing enterprises, as well as wastewater from other enterprises containing difficultly oxidized organic compounds and high concentrations of ammonium salts. 